\title{
Poor antibody response against human papillomavirus in adult-onset laryngeal papillomatosis
}

\author{
L.-M. AALTONEN*†, E. AUVINEN*, J. DILLNER\&\|, M. LEHTINEN\|, J. PAAVONEN*, H. \\ RIHKANEN†, and A. VAHERI* \\ * Department of Virology, Haartman Institute, University of Helsinki, Departments of $\uparrow$ Otorhinolaryngology and \\ *Gynecology and Obstetrics, Helsinki University Central Hospital, §Microbiology and Tumor Biology Center, \\ Karolinska Institute, Stockholm, Sweden and ||National Public Health Institute, Helsinki, Finland
}

\begin{abstract}
To investigate whether adult-onset laryngeal papillomatosis induces serum antibodies to the human papillomavirus (HPV), 60 patients underwent a clinical examination, and HPV DNA from their laryngeal biopsy was assayed by PCR and HPV serology with virus-like particles as the antigen. Patients and controls $(n=53)$ showed no differences in their HPV 6 and 16 antibodies. Patients more often had HPV 11 antibodies, female patients more often than female controls or male patients. Of the female patients, 5 of 15 had a history of genital condylomas and, at the follow-up visit, 5 of 9 had cervical cytology consistent with genital HPV infection. The fact that HPV antibodies did not correlate with clinical features of the laryngeal disease or with HPV DNA detected in the larynx, suggests that HPV antibodies in female patients were induced by genital rather than laryngeal HPV infection. The high prevalence of abnormal Pap smears indicates that gynaecological examination of female adult-onset laryngeal papilloma patients is warranted.
\end{abstract}

\section{Introduction}

Human papillomavirus (HPV) types 6 and 11 are associated with both genital condylomas and laryngeal papillomatosis, the latter being a rate condition with an incidence of 3.8/million/year [1]. A serological assay based on assembled virus-like particles (VLPs), also called capsids, is the most extensively used and validated method for type-specific serodiagnosis of HPV infection. Most studies on the HPV antibody response have focused on genital HPV infection [2-4]. Antibodies to HPV 11 virions have also been detected in juvenile-onset laryngeal papillomatosis [5]. Only one report exists on adult-onset laryngeal papilloma patients; it included only 15 patients and employed a firstgeneration HPV serology assay based on the L2 antigen, with limited HPV type-specificity [6].

Therefore, this study investigated whether adult-onset laryngeal papillomatosis induces a humoral immune response against HPV 6, 11 and 16 VLPs, and related HPV antibody response to clinical features and the

Received 6 July 2000; revised version accepted 2 Nov. 2000. Corresponding author: Dr L.-M. Aaltonen

(e-mail: Leena-Maija.Aaltonen@helsinki.fi).
HPV type detected by PCR in laryngeal papilloma tumour biopsies.

\section{Patients and methods}

Informed consent was obtained from all patients in this study. The human experimentation guidelines of Helsinki University Central Hospital were followed, and the study was approved by the institutional ethics committees of the Department of Otorhinolaryngology and Department of Gynecology and Obstetrics.

This study was based on adult-onset (age at diagnosis $\geqslant 17$ years) laryngeal papilloma patients, without malignant transformation, treated at Helsinki University Central Hospital, Department of Otorhinolaryngology, during the 20 years 1975-1994. These patients have already been investigated for HLA associations and HPV DNA was detected by PCR assay in the patients' most recent laryngeal papilloma biopsies [7]. The patients filled in a questionnaire, were examined by an otorhinolaryngologist, and had their larynxes videorecorded. A blood sample was drawn for HPV antibody assay. 
Sixty adult-onset laryngeal papilloma patients with the typical, $3: 1$, male : female distribution for the disease entered the study: 45 males, mean age 52 (range 2677) years and 15 females, mean age 48 (range 27-71) years. Because female patients had serum HPV 11 antibodies more often than female controls or male patients, they were invited to a second visit on average 1.3 (range 1-1.5) years later. They were re-examined by an otorhinolaryngologist, underwent mouth-washes and mouth-brush sampling, and had a gynaecological examination, Pap smear and colposcopically directed biopsy. The reference population comprised 53 age and sex-matched blood donors (13 females, 40 males) of unknown HPV status who visited Finnish Red Cross Blood Transfusion Units. It was impossible to find agematched blood donor controls for five male and two female patients of advanced age.

Details of the method for detecting HPV DNA by PCR and Southern blotting are described elsewhere [7]. After deparaffinisation and DNA purification of laryngeal papilloma tumour biopsies, PCR was performed on all laryngeal specimens with $\beta$-globin primers [8] and type-specific primers for HPV 6, 11 and 16 [9]. Laryngeal specimens negative with typespecific primers, as well as cervical biopsies and samples collected by mouth-wash and mouth-brush, were subjected to PCR with the general HPV primers $\mathrm{GP} 5+/ 6+[10]$.

HPV antibodies were detected by a standard enzyme immunoassay (EIA) based on baculovirus-expressed capsids [3, 2, 11] (a gift from Dr John T. Schiller, National Cancer Institute, Bethesda, MD, USA). Serum samples were tested at 1 in 30 dilution. Purified capsids were diluted to $50 \mathrm{ng} / \mathrm{ml}$ in ice-cold PBS, coated on EIA plates and held overnight at $4{ }^{\circ} \mathrm{C}$. The plates were then blocked with horse serum 10\% in PBS for 60 min at $37^{\circ} \mathrm{C}$ and incubated with human serum for $90 \mathrm{~min}$ at $37^{\circ} \mathrm{C}$. Bound $\mathrm{IgG}$ antibodies were detected by incubation with a monoclonal antibody (MAb) against $\gamma$ chain (Eurodiagnostics, Apeldoorn, The Netherlands); diluted ( 1 in 1000) for $90 \mathrm{~min}$ at $37^{\circ} \mathrm{C}$. Bound MAbs were detected with a goat anti-mouse $\gamma$-chain horseradish-peroxidase conjugate (Southern Biotechnology, Birmingham, AL, USA; diluted 1 in 2000). ABTS peroxidase substrate was applied and the results were measured as differences in optical density between antigen-coated and negative control plates reacting with the same serum and developed identically.

Negative control plates were coated and treated identically to the plates coated with HPV 6, 11 and 16 capsids, except that they were coated with disrupted capsids of the bovine papillomavirus. The patient and control sera were run simultaneously in the EIA plates. The cut-off levels used to assign seropositivity from absorbance values were pre-assigned and (relative to the internal standard sera) were the same levels used in previous studies $[2,11]$. The levels were arbitrarily assigned in the original studies $[2,11]$.

Pearson's $\chi^{2}$ test and Fisher's exact test were used for statistical analysis.

\section{Results}

HPV 6 and 16 antibodies were equally frequent in patients and controls (23\% versus $21 \%$ and $22 \%$ versus $23 \%$ ), with HPV 11 antibodies more frequent in patients ( $33 \%$ versus $15 \%, p=0.03$, Pearson's $\chi^{2}$ test). Female patients had HPV 11 antibodies more often than did male patients ( $60 \%$ versus $24 \%, \mathrm{p}=0.01$, Pearson's $\chi^{2}$ test) or female controls $(60 \%$ versus $15 \%$, $\mathrm{p}=0.02$, Pearson's $\chi^{2}$ test). The presence of serum HPV antibodies did not correlate with HPV DNA type in patients' laryngeal biopsies (Table 1), with the time interval between laryngeal biopsy and serum sampling for the HPV antibody assay which was $<1$ year in 6 patients, $1-3$ years in 10 patients and $>3$ years in 44 patients, with the number of laryngeal procedures, or with relapse (in 14 patients), as detected by clinical examination. In summary, 26 of the patients either suffered a laryngeal relapse when blood was drawn or their laryngeal papilloma biopsy had been taken $<1$ year before the serum sample. Of the female patients, 5 of 15 had a self-reported history of genital condylomas.

The study then investigated whether the HPV 11 antibodies in the female patients could have been caused by oral or by genital HPV infection. Of the 15

Table 1. HPV PCR results from male and female patients' laryngeal specimens and distribution of HPV antibodies in their serum samples

\begin{tabular}{lcccc}
\hline & \multirow{2}{*}{$\begin{array}{c}\text { Number of } \\
\text { patients }(\mathrm{n}=59)^{*}\end{array}$} & \multicolumn{3}{c}{ Number of patients with antibodies to } \\
\cline { 3 - 5 } HPV type in PCR & 20 & 6 & HPV 11 & HPV 16 \\
\hline HPV 6 & 8 & 0 & 2 & 7 \\
HPV 11 & 2 & 0 & 0 & 2 \\
Other HPV type & 14 & 3 & 5 & 3 \\
HPV-negative samples & 16 & 4 & 5 & 1 \\
Samples not amplifiable & 16 &
\end{tabular}

* One patient's laryngeal biopsy was not available for PCR, and one had both HPV 6 and HPV 11 DNA in her biopsy. Her sample was included both as an HPV 6-positive and as an HPV 11positive sample. 
female patients, nine underwent a thorough re-examination (see Patients and methods); 5 (56\%) of them had cervical cytology consistent with an HPV infection, and three of these also had histological features of HPV infection in cervical biopsy. Only three female patients had HPV 11 antibodies in their second blood sample; they all had Pap smear cytology consistent with an HPV infection. HPV DNA was detected in one cervical biopsy with general HPV primers, but all mouth-wash and mouth-brush samples were HPVnegative. Cytological examination of mouth-brush samples disclosed no features of HPV infection.

\section{Discussion}

Serology is a potentially useful method for screening for HPV infections and associated malignancies, but in adult-onset laryngeal papillomatosis it seems to be of little value. Neither clinical features of the disease nor the virus type detected in patients' laryngeal biopsies correlated with the presence of HPV antibodies. The present study was based on a clinically and histologically verified adult-onset laryngeal papilloma patient population treated over a 20 -year period in a large ENT unit. If antibodies against HPV 6, 11 and 16 VLPs have clinical relevance, this should have been discovered in this type of large series. The lack of correlation between HPV antibodies and number of laryngeal procedures performed or relapse detected in clinical examination argue against the clinical relevance of HPV antibodies. Tachezy et al. [6] reported that patients who had undergone $>20$ lifetime endolaryngeal procedures $(n=4)$ had high HPV antibody levels. However, $75 \%$ of these patients were females with chronic juvenile-onset laryngeal papillomatosis. Adultonset laryngeal papillomatosis is a disease with a 2-4fold male predominance $[12,13]$, and the present study found no difference in HPV antibodies between male patients and controls.

Only HPV 11 antibodies were found more frequently in patients than in controls. This contrasts with the fact that HPV 6 DNA is more commonly detected in adultonset patients' laryngeal biopsies than is HPV 11 DNA $[7,14]$. Moreover, the serum antibody response did not correlate with the HPV DNA type found in the larynx, although many studies of genital HPV infection have demonstrated the HPV type-specificity of the serological method used [2-4].

Because the serum samples were taken on average 8 years after the laryngeal samples, and no oral HPV infection was detected in the females at the second visit, it is possible that HPV antibodies induced by laryngeal infection might have been present earlier, but disappeared during follow-up. If so, such antibodies would be less stable over time than antibodies to HPV 16 [15]. Stability over time of HPV 6 and 11 antibody levels has not been widely studied, although a decline in antibody levels after clearance of HPV 6/11 DNA has been detected $[11,16]$. However, the lack of correlation between antibody prevalence and a current relapse in the larynx suggests inability to produce a response rather than poor antibody stability.

Pap smear cytology consistent with genital HPV infection was found in a high proportion (five of nine) of female patients and, in the follow-up visit, HPV 11 seropositivity was found only in these females, not among those who suffered a laryngeal relapse $(n=2)$. Thus, the results of the present study suggest that adult-onset laryngeal papillomatosis does not readily induce serum HPV antibodies, that HPV serology is not clinically relevant in the management of this disease, and that female patients' increased serum HPV antibodies may be due to genital HPV infection. A clinically relevant finding was the high prevalence of abnormal Pap smears in females with adult-onset laryngeal papillomatosis (elevated 70-fold compared with that of the general population in Finland [17]); therefore, gynaecological examination of these patients is recommended.

We thank Drs Torsten Wahlström and Pekka Nieminen for histological and cytological analyses, and Dr John T. Schiller for serological reagents. This study was supported by grants from the Clinical Research Institute of Helsinki University Central Hospital and the Medical Research Council of the Academy of Finland. J. D. received support from the Nordic Academy for Advanced Studies.

\section{References}

1. Lindeberg H, Elbrønd O. Laryngeal papillomas: the epidemiology in a Danish subpopulation 1965-1984. Clin Otolaryngol 1990; 15: 125-131.

2. Wikström A, van Doornum GJJ, Quint WGV, Schiller JT, Dillner J. Identification of human papillomavirus seroconversions. J Gen Virol 1995; 76: 529-539.

3. Kimbauer R, Hubbert NL, Wheeler CM, Becker TM, Lowy DR, Schiller JT. A virus-like particle enzyme-linked immunosorbent assay detects serum antibodies in a majority of women infected with human papillomavirus type 16. J Natl Cancer Inst 1994; 86: 494-499.

4. Kjellberg L, Wang Z, Wiklund F et al. Sexual behaviour and papillomavirus exposure in cervical intraepithelial neoplasia: a population-based case-control study. J Gen Virol 1999; 80: 391-398.

5. Bonnez W, Kashima HK, Leventhal B et al. Antibody response to human papillomavirus (HPV) type 11 in children with juvenile-onset recurrent respiratory papillomatosis (RRP). Virology 1992; 188: 384-387.

6. Tachezy R, Hamsikova E, Valvoda $\mathrm{J}$ et al. Antibody response to a synthetic peptide derived from the human papillomavirus type 6/11 L2 protein in recurrent respiratory papillomatoisis: correlation between Southern blot hybridization, polymerase chain reaction, and serology. J Med Virol 1994; 42: 52-59.

7. Aaltonen L-M, Partanen J, Auvinen E, Rihkanen H, Vaheri A. HLA-DQ alleles and human papillomavirus DNA in adultonset laryngeal papillomatosis. J Infect Dis 1999; 179: $682-685$.

8. Saiki RK, Scharf S, Faloona F et al. Enzymatic amplification of $\beta$-globin genomic sequences and restriction site analysis for diagnosis of sickle cell anemia. Science 1985; 230: 13501354.

9. van den Brule AJC, Claas ECJ, du Maine M et al. Use of anticontamination primers in the polymerase chain reaction for the detection of human papilloma virus genotypes in cervical scrapes and biopsies. J Med Virol 1989; 29: 20-27.

10. de Roda Husman A-M, Walboomers JMM, van den Brule AJC, 
Meijer CJLM, Snijders PJF. The use of general primers GP5 and GP6 elongated at their $3^{\prime}$ ends with adjacent highly conserved sequences improves human papillomavirus detection by PCR. J Gen Virol 1995; 76: 1057-1062.

11. Wikström A, van Doornum GJJ, Kirnbauer R, Quint WGV, Dillner J. Prospective study on the development of antibodies against human papillomavirus type 6 among patients with condyloma accuminata or new asymptomatic infection. $J$ Med Virol 1995; 46: 368-374.

12. Capper JWR, Bailey CM, Michaels L. Squamous papillomas of the larynx in adults. A review of 63 cases. Clin Otolaryngol 1983; 8: 109-119.

13. Lindeberg H, Elbrond O. Laryngeal papillomas: clinical aspects in a series of 231 patients. Clin Otolaryngol 1989; 14: 333-342.
14. Corbitt G, Zarod AP, Arrand JR, Longson M, Farrington WT. Human papillomavirus (HPV) genotypes associated with laryngeal papilloma. J Clin Pathol 1988; 41: 284-288.

15. af Geijersstam V, Kibur M, Wang Z et al. Stability over time of serum antibody levels to human papillomavirus type 16 . J Infect Dis 1998; 177: 1710-1714.

16. Carter JJ, Koutsky LA, Hughes JP et al. Comparison of human papillomavirus types 16,18 , and 6 capsid antibody responses following incident infection. J Infect Dis 2000; 181: 19111919.

17. Syrjänen K, Yliskoski M, Kataja V et al. Prevalence of genital human papillomavirus infections in a mass-screened Finnish female population aged $20-65$ years. Int J STD AIDS 1990; 1: $410-415$. 